DOI: $10.20473 / \mathrm{mi} . v 2 \mathrm{i} 3.14761$

Article history: Submitted 8 August 2019; Accepted 3 September 2019; Available online 1 October 2019.

\title{
Perlindungan Hukum bagi Pekerja di Perusahaan yang Tidak Membayar Iuran BPJS Ketenagakerjaan
}

\author{
Nurfatimah Mani \\ nunky.mani@gmail.com \\ Universitas Surabaya
}

\begin{abstract}
The company or employer has the right and responsibility to provide Labor social security to employees and their family members, in accordance with Law No. 13 of 2003 concerning Manpower and Law No. 24 of 2011 concerning BPJS. In practice, there are still many companies that do not pay BPJS Employment Dues on a regular and orderly basis so that there is arrears and blocking of Company accounts resulting in workers unable to receive their rights in accordance with the BPJS program that they follow. Companies most often use the excuse of not paying contributions because of financial problems. Workers will automatically not be able to make JHT, JKK, Pension, JKM claims which are the rights of workers and heirs if the Company does not pay the arrears. Therefore legal protection for workers is needed to guarantee their rights can be obtained according to applicable regulations. This paper will further examine how the legal protection for workers who work in companies where the company does not pay BPJS Labor contributions in accordance with the rules. The writing method used is normative juridical which examines more deeply the laws and supporting regulations related to legal protection for workers. The conclusion of this paper is that even though the supporting laws and regulations have been issued do not guarantee labor rights are fulfilled with certainty, so it requires efforts from law enforcers to supervise and impose sanctions on companies that violate and deliberately do not pay BPJS Employment contributions.
\end{abstract}

Keywords: Labor; Companies; BPJS Ketenagakerjaan Contributions; Legal Protection.

\begin{abstract}
Abstrak
Perusahaan atau pemberi kerja memiliki hak dan tanggungjawab untuk memberikan Jaminan sosial Tenaga Kerja kepada karyawan dan anggota keluarganya, sesuai dengan Undang-Undang No 13 Tahun 2003 tentang Ketenagakerjaan dan Undang-undang No. 24 Tahun 2011 tentang BPJS. Pada prakteknya Perusahaan masih banyak yang tidak membayar Iuran BPJS Ketenagakerjaan secara rutin dan tertib sehingga terjadi penunggakan dan pemblokiran rekening Perusahaan yang berakibat tenaga kerja tidak dapat menerima haknya sesuai dengan program BPJS yang diikutinya. Perusahaan paling sering menggunakan alasan tidak membayar iuran dikarenakan adanya permasalahan keuangan. Tenaga kerja secara otomatis tidak akan bisa melakukan klaim JHT, JKK, Pensiun, JKM yang menjadi hak tenaga kerja dan ahli warisnya bila Perusahaan tidak membayar tunggakannya. Oleh karena itu perlindungan hukum bagi tenaga kerja sangat dibutuhkan untuk menjamin hak - hak mereka dapat diperoleh sesuai aturan yang berlaku. Tulisan ini akan menelaah lebih jauh bagaimana perlindungan hukum bagi tenaga kerja yang bekerja di Perusahaan dimana Perusahaan tersebut tidak membayarkan iuran BPJS Ketenagakerjaan sesuai aturan. Metode penulisan yang digunakan adalah yuridis normative yang mengkaji lebih dalam Undang-undang dan peraturan pendukungnya terkait dengan perlindungan hukum bagi tenaga kerja. Kesimpulan dari penulisan ini adalah bahwa walaupun telah diterbitkan Undang-undang dan peraturan pendukungnya tidak menjamin hakhak tenaga kerja terpenuhi dengan pasti, sehingga perlu upaya dari para penegak hukum untuk mengawasi dan memberikan sanksi kepada Perusahaan yang melanggar dan dengan sengaja tidak membayarkan iuran BPJS Ketenagakerjaan.
\end{abstract}

Kata Kunci: Tenaga Kerja; Perusahaan; Iuran BPJS Ketenagakerjaan; Perlindungan Hukum. 


\section{Pendahuluan}

Pemerintah melalui Undang-Undang No. 13 Tahun 2003 tentang ketenagakerjaan berusaha memberikan perlindungan kepada pekerja. Dimana didalam pasal-pasalnya tercantum hak dan kewajiban pemberi kerja atau perusahaan dan juga hak serta kewajiban pekerja atau karyawannya. Setiap pekerja/buruh dan keluarganya berhak untuk memperoleh jaminan sosial tenaga kerja yang wajib dilaksanakan sesuai dengan peraturan perundang-undangan yang berlaku. ${ }^{1}$

Pada Undang-Undang No 24 Tahun 2011 tentang BPJS juga menjelaskan mengenai kewajiban pemberi kerja atau perusahaan dan kewajiban dari peserta yaitu karyawan atau para pekerjanya untuk mendaftar sebagai peserta BPJS dan membayar iuran kepesertaan BPJS. Pemberi kerja atau dalam hal ini perusahaan wajib memungut iuran BPJS dari pekerjanya dan juga wajib membayarkan iuran tersebut kepada BPJS secara periodik setiap bulannya. ${ }^{2}$

Dalam pelaksanaan pembayaran iuran ini, perusahaan dapat mengalami banyak kendala terutama dalam hal keuangan. Sehingga dalam implementasinya perusahaan dapat memungut iuran dari karyawannya dan tidak menyetorkannya ke BPJS Ketenagakerjaan. Beberapa perusahaan juga ada yang tidak memungut iuran dari pekerjanya, sehingga mereka tidak bisa dipersalahkan karena menggelapkan uang dari pekerjanya. Namun perusahaan tetap dianggap melakukan kesalahan karena perusahaan sudah diwajibkan memotong upah karyawan untuk membayar iuran BPJS dan kesalahan kedua adalah perusahaan juga tidak menyetor iuran sama sekali kepada BPJS.

Bila perusahaan tidak menyetorkan iuran BPJS Ketenagakerjaan, maka BPJS Ketenagakerjaan wajib menagih dan memberikan sanksi kepada perusahaan. Namun sebelum diberikan sanksi, BPJS Ketenagakerjaan akan melakukan tahapan - tahapan dalam pemberian sanksi sesuai dengan ketentuan Permenaker No. 4 tahun 2018 tentang Tata Cara Pengenaan dan Pencabutan Sanksi Administratif Tidak Mendapat Pelayanan Publik Tertentu Bagi Pemberi Kerja Selain Penyelenggara

\footnotetext{
${ }^{1}$ Pasal 99 ayat 1, Undang-Undang Republik Indonesia No. 13 Tahun 2003 tentang Ketenagakerjaan.

${ }^{2}$ Pasal 17 dan Pasal 19, Undang-undang Republik Indonesia No. 24 Tahun 2011 tentang BPJS.
} 
Negara. Sanksi kepada pemberi kerja atau perusahaan diawali dengan diberikannya sanksi administratif dimana perusahaan akan mendapatkan teguran tertulis, denda; dan/atau, tidak mendapat pelayanan publik tertentu. ${ }^{3}$ Setelah BPJS Ketenagakerjaan melaksanakan sanksi seperti yang disebutkan dalam Permenaker tersebut, Perusahaan juga dapat dikenakan sanksi pidana dimana perusahaan yang melanggar ketentuan sebagaimana dimaksud dalam Pasal 19 ayat (1) atau ayat (2) dipidana dengan pidana penjara paling lama 8 (delapan) tahun atau pidana denda paling banyak Rp1.000.000.000,00 (satu miliar rupiah). ${ }^{4}$

Ancaman sanksi pidana dengan denda atau kurungan penjara menjadi landasan bagi BPJS Ketenagakerjaan untuk memberikan peringatan kepada perusahan. Namun BPJS Ketenagakerjaan tidak menentukan berapa nilai yang menjadi kewajiban perusahaan yang tidak disetorkan dan berhak untuk dituntut. Selain itu bagi pekerja, dengan kondisi perusahaan kesulitan keuangan tidak membuat hak-hak mereka untuk mendapatkan benefit dari program BPJS Ketenagakerjaan menjadi boleh diabaikan. Kewajiban perusahaan tetap harus dijalankan sampai dengan adanya keputusan pailit atau perusahaan ditutup. Hal itupun tetap mengharuskan perusahaan untuk membayar semua kewajibannya kepada para pekerja.

Batasan pelanggaran hukumnya belum lengkap. Sehingga Penulis tertarik untuk mendalami lebih jauh mengenai perlindungan hukum bagi pekerja di perusahaan yang tidak membayar BPJS Ketenagakerjaan Tulisan ini akan fokus untuk mentelaah aturan dan Undang-Undang yang telah ditetapkan tentang perlindungan hukum bagi pekerja dan sanksi bagi perusahan yang tidak membayar iuran BPJS Ketenagakerjaan serta bagaimana solusi bagi tenaga kerja agar tetap dapat memperoleh haknya.

Rumusan masalah dalam penulisan ini adalah bagaimana perlindungan hukum bagi pekerja di perusahaan yang tidak membayar iuran BPJS Ketenagakerjaan.

${ }^{3}$ Pasal 2, Permanaker No 4 tahun 2018 tentang Tata Cara Pengenaan dan Pencabutan Sanksi Administratif Tidak Mendapat Pelayanan Publik Tertentu Bagi Pemberi Kerja Selain Penyelenggara Negara.

${ }^{4}$ Pasal 55, Undang - Undang No. 24 Tahun 2011 tentang BPJS. 


\section{Metodologi Penulisan}

Materi ini ditulis dengan menggunakan metode penelitian hukum normatif dan empiris. Metode penelitian hukum normatif atau metode penelitian hukum kepustakaan adalah metode atau cara yang dipergunakan di dalam penelitian hukum yang dilakukan dengan cara meneliti bahan pustaka yang ada. ${ }^{5}$ Tahapan pertama penelitian hukum normatif adalah penelitian yang ditujukan untuk mendapatkan hukum obyektif (norma hukum), yaitu dengan mengadakan penelitian terhadap masalah hukum. Tahapan kedua penelitian hukum normatif adalah penelitian yang ditujukan untuk mendapatkan hukum subjektif (hak dan kewajiban). ${ }^{6}$

Di dalam penelitian hukum terdapat beberapa pendekatan. Dengan pendekatan tersebut, peneliti akan mendapatkan informasi dari berbagai aspek mengenai isu yang sedang dicoba untuk dicari jawabnya. Macam-macam pendekatan-pendekatan yang digunakan di dalam penelitian hukum adalah $:^{7}$

1. Pendekatan undang-undang (statute approach);

2. Pendekatan kasus (case approach);

3. Pendekatan historis (historical approach);

4. Pendekatan komparatif (comparative approach);

5. Pendekatan konseptual (conceptual approach).

Tulisan ini ditulis berdasarkan pada pendekatan Undang-Undang. Pendekatan undang-undang dilakukan dengan menelaah semua undang-undang dan regulasi yang terkait dengan isu hukum yang sedang ditangani. ${ }^{8}$

Untuk melengkapi penelitian hukum normatif, penulis juga melakukan penelitian hukum empiris (penelitian lapangan) yang mana dalam penelitian lapangan ini yang dicari adalah kebiasaan, perjanjian, law enforcement, maupun kesadaran hukum. ${ }^{9}$ Dalam penelitian hukum empiris ini akan dilihat fakta-fakta yang ada di dalam suatu masyarakat, badan hukum atau badan pemerintah untuk melihat bagaimana hukum dijalankan dimasyarakat.

\footnotetext{
${ }^{5}$ Soerjono Soekanto dan Sri Mamudji, Penelitian Hukum Normatif Suatu Tinjauan Singkat (Raja Grafindo Persada 2009).[13-14].

${ }^{6}$ Hardijan Rusli, Metode Penelitian Hukum Normatif: Bagaimana? (Law Review 2006).[50].

${ }^{7}$ Peter Mahmud Marzuki, Penelitian Hukum 2009, (Kencana Prenada Media Group 2009)[93].

${ }^{8}$ ibid.[93].

${ }^{9}$ Sudikno dan A Pitl Mertokusumo, Penemuan Hukum Sebuah Pengantar (2009).[30].
} 


\section{Kewajiban Perusahaan dalam Kepesertaan BPJS Ketenagakerjaan}

Dalam Undang-Undang No 24 Tahun 2011 tentang BPJS telah disebutkan dalam pasal 15 tentang kewajiban perusahaan yaitu secara bertahap wajib mendaftarkan dirinya dan pekerjanya sebagai Peserta kepada BPJS sesuai dengan program Jaminan Sosial yang diikuti, perusahan wajib memberikan data dirinya dan pekerjanya berikut anggota keluarganya secara lengkap dan benar kepada BPJS, dan tahapan sebagaimana dimaksud pada ayat (1) diatur dengan Peraturan Presiden.

Definisi pemberi kerja dalam UU No. 24 Tahun 2011 tentang BPJS adalah orang perseorangan, pengusaha, badan hukum, atau badan lainnya yang mempekerjakan tenaga kerja atau Penyelenggara Negara yang mempekerjakan pegawai negeri dengan membayar gaji, upah, atau imbalan dalam bentuk lainnya. ${ }^{10}$ Dalam pembahasan ini pemberi kerja yang dimaksud adalah Perusahaan.

Besarnya iuran yang wajib disetorkan kepada BPJS Ketenagakerjaan dicantumkan dalam Peraturan Pemerintah No. 84 Tahun 2013 tentang perubahan kesembilan atas Peraturan Pemerintah nomor 14 tahun 1993 tentang penyelenggaraan program jaminan sosial tenaga kerja. Pada pasal 9 menyebutkan kewajiban iuran sebagai berikut :

Pasal 9

1. Besarnya iuran program jaminan sosial tenaga kerja adalah sebagai berikut:

a. Jaminan Kecelakaan kerja yang perincian besarnya iuran berdasarkan kelompok jenis usaha sebagaimana tercantum dalam Lampiran 1, sebagai berikut:

- Kelompok I: 0,24\% dari upah sebulan;

- Kelompok II: 0,54\% dari upah sebulan;

- Kelompok III: 0,89\% dari upah sebulan;

- Kelompok IV: $1,27 \%$ dari upah sebulan;

- Kelompok V: 1,74\% dari upah sebulan;

b. Jaminan Hari Tua, sebesar 5,70\% dari upah sebulan;

c. Jaminan Kematian, sebesar 0,30\% dari upah sebulan;

d. Dihapus.

2. Iuran Jaminan Kecelakaan Kerja dan Jaminan Kematian ditanggung sepenuhnya oleh pengusaha.

3. Iuran jaminan Hari Tua sebagaimana dimaksud dalam ayat 1 huruf $b$, sebesar

${ }^{10}$ Pasal 1 angka 9 Undang-undang RI No 24 Tahun 2011 tentang BPJS. 
$3,70 \%$ ditanggung oleh pengusaha dan sebesar $2 \%$ ditanggung oleh tenaga kerja. 4. Dihapus.

5. Ketentuan Pasal 33 sampai dengan Pasal 46 dihapus.

Peraturan Pemerintah ini merupakan ketentuan yang wajib dijalankan oleh perusahaan. Pembayaran iuran tersebut dilakukan secara periodik per-bulan kepada BPJS Ketenagakerjaan. Penunggakan pembayaran iuran akan berakibat tidak berlakukan pelayanan ataupun benefit yang dapat diterima oleh pekerjanya. Sebagai contoh, bilamana perusahaan tidak membayar iuran BPJS Ketenagakerjaan, maka ketika pekerja ingin mencairkan JHT maka mereka tidak dapat mengklaim JHT tersebut kepada BPJS Ketenagakerjaan. Demikian pula ketika terjadi kecelakaan kerja di dalam periode tunggakan terjadi atau didalam periode perusahaan belum membayar iurannya maka pekerja tidak dapat meng-klaim pengobatan atau perawatan di Rumah Sakit akibat kecelakaan kerja tersebut. Dengan tidak terpenuhinya klaim para pekerja maka secara langsung para pekerja dirugikan. Sementara perusahaan bisa jadi sudah memotong iuran dari gaji para pekerjanya namun tidak disetorkan kepada BPJS Ketenagakerjaan.

Iuran BPJS Ketenagakerjaan harus dibayarkan paling lama tanggal 15 setiap bulan. Keterlambatan pembayaran akan dikenakan denda 2\% untuk setiap bulan keterlambatan.

\section{Program Jaminan Hari Tua (JHT)}

JHT merupakan manfaat yang diberikan saat peserta tidak lagi aktif bekerja. Manfaat yang diberikan merupakan uang tunai yang berasal dari akumulasi iuran BPJS Ketenagakerjaan disertai bunga hasil pengembangan dana. Bila ingin melakukan pencairan dana JHT, peserta harus memenuhi sejumlah persyaratan yang tertulis dalam Peraturan Menteri. ${ }^{11}$

\section{Program Jaminan Kecelakaan Kerja (JKK)}

Program BPJS Ketenagakerjaan selanjutnya adalah Jaminan Kecelakaan Kerja (JKK). Program ini memberikan manfaat perlindungan resiko kecelakaan

\footnotetext{
11 Permenaker No 19 Tahun 2015 tentang Tata Cara Pembayaran Manfaat JHT.
} 
yang berhubungan dengan pekerjaan, baik di tempat kerja, maupun kecelakaan menuju tempat kerja. ${ }^{12}$

\section{Program Jaminan Kematian}

Program BPJS Ketenagakerjaan selanjutnya adalah program Jaminan Kematian (JK). Program ini diberikan dalam bentuk uang tunai kepada ahli waris ketika peserta meninggal dunia yang bukan disebabkan karena kecelakaan kerja. ${ }^{13}$

\section{Program Jaminan Pensiun}

Program BPJS Ketenagakerjaan terakhir yang ditetapkan Pemerintah adalah Jaminan Pensiun. Program ini diberikan oleh BPJS Ketenagakerjaan untuk mempertahankan kehidupan yang layak bagi para peserta atau ahli waris setelah memasuki usia pensiun atau mengalami cacat. ${ }^{14}$

Iuran yang harus dibayarkan untuk program JP adalah masing-masing 1\% oleh pekerja dan 2\% oleh perusahaan. Besaran iuran BPJS Ketenagakerjaan untuk program JP berubah setiap tahunnya karena mengikuti tingkat inflasi umum yang berlaku tahun sebelumnya.

\section{Sanksi terhadap Perusahaan yang Tidak Membayar Iuran BPJS Ketenagakerjaan}

Definisi pemberi kerja dalam UU No. 24 Tahun 2011 tentang BPJS adalah orang perseorangan, pengusaha, badan hukum, atau badan lainnya yang mempekerjakan tenaga kerja atau Penyelenggara Negara yang mempekerjakan pegawai negeri dengan membayar gaji, upah, atau imbalan dalam bentuk lainnya. ${ }^{15}$ Dalam pembahasan ini pemberi kerja yang dimaksud adalah Perusahaan.Perusahaan

\footnotetext{
12 Permenaker No 44 Tahun 2015 tentang Penyelenggaraan Program Jaminan Kecelakaan Kerja dan Jaminan Kematian.

13 ibid.

14 Peraturan Menteri Ketenagakerjaan Nomor 29 Tahun 2015 tentang Tata Cara Pendaftaran Kepesertaan, Pembayaran dan Penghentian Manfaat Jaminan Pensiun.

15 Pasal 1 angka 9 Undang-undang RI No 24 Tahun 2011 tentang BPJS.
} 
memiliki kewajiban untuk membayar dan memungut iuran yang menjadi beban peserta (pekerja di perusahaan) dan selanjutnya menyetorkannya kepada BPJS. ${ }^{16}$ Sanksi bagi perusahaan yang tidak melaksanakan ketentuan dalam Pasal 15 dan Pasal 16 Undang - Undang No. 24 Tahun 2011 dinyatakan dalam Pasal 17dan Pasal 55 sebagai berikut:

Pasal 17

1. Pemberi Kerja selain penyelenggara negara yang tidak melaksanakan ketentuan sebagaimana dimaksud dalam Pasal 15 ayat (1) dan ayat (2), dan setiap orang yang tidak melaksanakan ketentuan sebagaimana dimaksud dalam Pasal 16 dikenai sanksi administratif.

2. Sanksi administratif sebagaimana dimaksud pada ayat (1) dapat berupa:

a. teguran tertulis;

b. denda; dan/atau

c. tidak mendapat pelayanan publik tertentu.

3. Pengenaan sanksi sebagaimana dimaksud pada ayat (2) huruf a dan huruf $b$ dilakukan oleh BPJS.

4. Pengenaan sanksi sebagaimana dimaksud pada ayat (2) huruf c dilakukan oleh pemerintah atau pemerintah daerah atas permintaan BPJS.

5. Ketentuan lebih lanjut mengenai tata cara pengenaan sanksi administratif diatur dengan Peraturan Pemerintah.

Pasal 55

Pemberi Kerja yang melanggar ketentuan sebagaimana dimaksud dalam Pasal 19 ayat (1) atau ayat (2) dipidana dengan pidana penjara paling lama 8 (delapan) tahun atau pidana denda paling banyak Rp1.000.000.000,00 (satu miliar rupiah).

Dalam pelaksanaannya perusahaan yang tidak membayar Iuran BPJS Ketenagakerjaan masih cukup banyak dan rata-rata mereka terkendala dengan permasalahan keuangan. Semakin sulit perusahaan menjalankan roda operasionalnya maka semakin besar beban perusahaan untuk melaksanakan kewajibannya.

Perusahaan yang tidak membayar iuran BPJS sampai dengan 3 bulan berturut-turut, maka pekerjanya tidak bisa melakukan klaim atas seluruh manfaat dari BPJS Ketenagakerjaan sampai dengan Perusahaan melakukan pelunasan iuran yang tertunggak. ${ }^{17}$ Hal ini sangat merugikan pekerja dan keluarganya.

\footnotetext{
16 Pasal 19 Undang-undang RI No 24 Tahun 2011 tentang BPJS Ketenagakerjaan.

17 Pasal 19 Undang-undang RI No 24 Tahun 2011 tentang BPJS.
} 
Walaupun pekerja sudah dipungut iuran secara rutin untuk membayar BPJS Ketenagakerjaan namun perusahaan tidak menyetorkannya maka merekapun tetap tidak bisa memperoleh haknya.

Keadaan ini yang menjadi permasalahan bagi pekerja dan perusahaan, dimana BPJS Ketenagakerjaan tidak memberikan peluang bagi pekerja untuk mendapatkan manfaat sesuai peraturan walaupun mereka telah dipungut iuran selama bertahuntahun bekerja di perusahaan. Kondisi ekonomi atau financial perusahaan yang sedang tidak baik sehingga perusahaan lalai membayar iuran disaat ini mengakibatkan iuran yang bertahun-tahun dikumpulkan atau disetorkan ke BPJS menjadi terblokir atau tidak dapat diklaim. Tentu saja yang dirugikan adalah pekerjanya.

\section{Pelaksanaan Sanksi terhadap Perusahaan yang Tidak Membayar Iuran BPJS} Ketenagakerjaan

Dalam implementasinya, BPJS Ketenagakerjaan sudah berupaya untuk menerapkan sanksi yang sesuai kewenangannya, namun masih ada Perusahaan yang tidak membayar iuran yang seharusnya mereka lakukan. Beberapa Perusahaan memiliki kendala keuangan yang menjadi alasan terkuat sehingga tidak sanggup membayar iuran secara rutin. Sementara itu ada juga beberapa Perusahaan yang dengan sengaja tidak membayar Iuran BPJS Ketenagakerjaan dengan maksud mengurangi biaya operasional mereka dengan sengaja, misalkan dengan cara tidak mendaftarkan beberapa pekerjanya atau dengan tidak membayar iuran yang menjadi kewajibannya tanpa sebab.

Pemerintah berupaya untuk melindungi para pekerja dan juga mengawasi perusahaan agar dapat secara rutin melaksanakan kewajibannya melalui Peraturan Pemerintah Nomor 86 Tahun 2013 tentang Tata Cara Pengenaan Sanksi Administratif kepada Pemberi Kerja Selain Penyelenggara Negara dan Setiap Orang, Selain Pemberi Kerja, Pekerja, dan Penerima Bantuan Iuran dalam Penyelenggara Jaminan Sosial dan Peraturan Menteri Tenaga Kerja No. 23 tahun 2016 tentang Prosedur Pengenaan dan Pencabutan Sanksi Administratif Tidak Mendapatkan Layanan Publik Tertentu untuk Pengusaha Selain Administrator 
Negara. Selain itu melalui Undang - Undang Ri No. 24 Tahun 2011 tentang BPJS juga telah disebutkan mengenai sanksi bagi perusahaan yang melalaikan tanggungjawabnya membayar iuran.

Tata cara pengenaan sanksi kepada pemberi kerja atau perusahaan adalah sebagai berikut:

1) Pengenaan sanksi teguran tertulis diberikan paling banyak 2 (dua) kali masingmasing untuk jangka waktu paling lama 10 (sepuluh) harikerja oleh BPJS. Teguran tertulis pertama untuk jangka waktu 10 hari, apabila sampai dengan berakhinya jangka waktu 10 hari sanksi teguran tertulis pertama Pemberi kerja selain penyelenggara Negara tidak melaksanakan kewajibannya, BPJS mengenakan sanksi teguran tertulis kedua untuk jangka waktu 10 hari.

2) Apabila pada masa teguran tertulis pemberi kerja tidakjuga mendaftarkan pekerjanya dalam keanggotaan BPJS Ketenagakerjaan maka pemberi kerja akan dikenakan sanksi denda oleh BPJS, yang diberikan untuk jangka waktu paling lama 30 (tiga puluh) hari sejak berakhirnya pengenaan sanksi teguran kedua berakhir. Besarnya denda yang dikenakan adalah0,1\% (nol koma satu persen) setiap bulan dari iuran yang seharusnya dibayar yang dihitung sejak teguran tertulis kedua berakhir yang disetorkan kepada BPJS bersamaan dengan pembayaran iuran berikutnya. Denda sebagaimana dimaksud menjadi pendapatan lain dari dana jaminan sosial.

3) Apabila sanksi berupa denda tidak disetor lunas, pemberi kerja selain Peneyelenggara Negara dikenai sanksi tidak mendapat pelayanan publik tertentu yang dilakukan oleh Pemerintah, pemerintah daerah provinsi, atau pemerintah daerah kabupaten/kota atas permintaan BPJS yang meliputi:

a) perizinan terkait usaha;

b) izin yang diperlukan dalam mengikuti tender proyek;

c) izin memperkerjakan tenaga asing;

d) izin perusahaan penyedia jasa pekerja/buruh; atau

e) izin Mendirikan Bangunan (IMB).

Sanksi tidak mendapat pelayanan publik tertentu dicabut apabila:

a) Denda telah disetor secara lunas kepada BPJS dan telah mendaftarkan 
dirinya dan pekerjanya sebagai peserta kepada BPJS secara bertahap sesuai dengan program jaminan sosial yang diikutinya bagi pemberi kerja selain Penyelenggara Negara yang melanggar kewajibannya sebagaimana dimaksud dalam Pasal 3 ayat (1) huruf a Undang-undang No 24 Tahun 2011;atau

b)Telah memberikan data dirinya dan pekerjanya berikut anggota keluarganya kepada BPJS secara lengkap dan benar bagi pemberi kerja Selain Penyelenggara Negara yang melanggar kewajiban sebagaimana dimaksud dalam pasal 3 ayat (1) huruf $b$.

Sehubungan dengan itu, dengan bukti lunas pembayaran denda, pendaftaran kepesertaan, dan bukti pemberian data kepesertaan yang lengkap dan benar dijadikan sebagai dasar pencabutan sanksi tersebut. Sanksi yang diberikan secara bertahap tidak selalu diberikan sesuai dengan tahapannya. Hal ini dikarenakan kerjasama BPJS Ketenagakerjaan dengan aparatur penegak hukum belum terjalin dengan erat. Perusahaan baru akan mendapatkan sanksi administratif bila BPJS Ketenagakerjaan melaporkan kondisi perusahaan tersebut kepada instansi yang berkepentingan misalkan dengan Dinas Tenaga Kerja. Dengan demikian perusahaan yang akan mengajukan perijinan kepada Dinas Tenaga Kerja diwajibkan terlebih dahulu untuk membayar tunggakannya. Dinas Tenaga Kerja seharusnya bisa menerapkan sanksi dengan tegas bila tidak dibayarkan iurannya maka perijinannya tidak akan dilayani, namun hal ini jarang terjadi. Dinas Tenaga Kerja seringkali hanya memberikan Surat Peringatan dan tidak ada pelaksanaan sanksi yang diberikan sesuai Undang-Undang. Pada kenyataannya BPJS Ketenagakerjaan memberikan toleransi kepada perusahaan sehingga denda terus berjalan dan akibatnya semakin panjang waktu yang dibutuhkan untuk bisa mengajukan klaim bagi para pekerjanya.

Di wilayah Jakarta Barat dimana beberapa perusahaan yang menunggak mendapatkan SKK (Surat Kuasa Khusus). SKK adalah Surat Kuasa Khusus yang dikeluarkan oleh BPJS Ketenagakerjaan dan diberikan kepada Kejari untuk diproses lebih lanjut. Berdasarkan SKK tersebut Kejari melaksanakan perannya 
untuk memberikan Surat Peringatan kepada perusahaan yang menunggak pembayaran Iuran. Jumlah nilai tunggakan tidak menjadi perhatian Kejari, namun lamanya Perusahaan tidak membayar Iuran yang mendasari Kejari atau BPJS Ketenagakerjaan melaporkan perusahaan. Biasanya yang dilaporkan dan mendapat SKK adalah mereka yang lebih dari 1 tahun tidak membayar iuran.

Penerapan dari satu kasus ke kasus lainnya menjadi berbeda. BPJS Ketenagakerjaan tidak menentukan besar atau nilai tunggakan melainkan berdasarkan periode waktu sebuah perusahaan tidak membayar iuran BPJS Ketenagakerjaan. Dengan demikian perusahaan tidak mengetahui nilai tunggakan yang pasti dapat membuat perusahaan mendapat sanksi.

Tabel 1. Daftar nama Perusahaan yang menunggak Iuran BPJS Ketenagakerjaan dan mendapat SKK dari BPJS Ketenagakerjaan Jakarta Barat.

\begin{tabular}{|c|l|r|r|r|}
\hline NO. SKK & \multicolumn{1}{|c|}{ NAMA PERUSAHAAN } & \multicolumn{1}{c|}{ PIUTANG } & \multicolumn{1}{c|}{ DENDA } & \multicolumn{1}{c|}{ TOTAL } \\
\hline 1 & JAYA MAJU PERKASA CV & $1.002 .658 .184,64$ & $370.983 .528,30$ & $1.373 .641 .712,94$ \\
\hline 2 & KARINA ENVELOPE PT & $202.258 .000,00$ & $56.612 .649,60$ & $258.903 .043,60$ \\
\hline 3 & AA PLASTIK DAN LOGAM & $34.136 .134,56$ & $18.664 .114,18$ & $52.800 .248,74$ \\
\hline 4 & QSMART ASSISTANCE PT & $164.759 .442,11$ & $41.189 .800,50$ & $205.949 .302,61$ \\
\hline 5 & PT MULTI VIDA & $5.740 .800,00$ & $1.205 .568,00$ & $6.946 .361,00$ \\
\hline 6 & SMK TARUNA TERPADU & $38.688 .000,00$ & $8.124 .480,00$ & $46.812 .480,00$ \\
\hline 7 & SMP TARUNA TERPADU & $34.771 .220,00$ & $7.301 .952,00$ & $42.073 .152,00$ \\
\hline 8 & YIC AL GHAZALI BOGOR & $29.414 .400,00$ & $6.177 .024,00$ & $35.591 .424,00$ \\
\hline 9 & PRIMATAMA SEMESTA, PO & $20.222 .399,76$ & $4.246 .703,00$ & $24.469 .103,66$ \\
\hline 10 & PANDA MAS KIMIA ABADI PT & $17.184 .960,00$ & $3.608 .841,60$ & $20.793 .801,60$ \\
\hline 11 & RA TARBIATUN NISSA & $12.268 .800,00$ & $2.576 .529,00$ & $14.845 .248,00$ \\
\hline 12 & IP TEKNOLOGI KOMUNIKASI PT & $30.171 .636,00$ & $5.732 .610,84$ & $35.528 .112,00$ \\
\hline 13 & INDRAMAS EWIRO KARYA PT & $4.773 .600,00$ & $859.248,00$ & $5.632 .042,00$ \\
\hline 14 & CITRA RAJAWALI EMAS & $15.536 .476,00$ & $2.756 .565,83$ & $18.333 .042,63$ \\
\hline 15 & KAYU PRATAMA INDONESIA & $12.831 .935,00$ & $2.461 .164,25$ & $15.493 .099,85$ \\
\hline 16 & TRIINTE INTERNAYIONAL PT & $4.264 .914,42$ & $639.737,07$ & $4.904 .651,49$ \\
\hline 17 & KAN BASAH UD & $1.336 .296,00$ & $146.992,56$ & $1.483 .288,56$ \\
\hline 18 & PUTRA SUMBER PATRICINDO,PT & $842.400,00$ & $84.240,00$ & $926.640,00$ \\
\hline
\end{tabular}

Source: Kejari Jakarta Barat

Perbedaan nilai tunggakan tidak dipertimbangkan untuk mengeluarkan SKK tersebut. Oleh karena itu perusahaan harus dapat mengantisipasi periode tunggakan yang harus diselesaikannya. Perusahaan tentunya memiliki Kemampuan keuangan yang berbeda-beda, sehingga dasar dari penetapan SKK ini tidak bisa didasari dari nilai tunggakannya. Ada resiko yang terjadi dimana Hakim dalam menentukan 
putusan menjadi subyektif atau menjadi harus benar-benar hati-hati agar tidak merugikan para pekerja diperusahaan.

Penerapan sanksi dengan dikeluarkannya SKK ini merupakan tahapan awal dari BPJS Ketenagakerjaan untuk dapat mengajukan tuntutan bagi perusahaan untuk membayar iuran beserta dendanya. Dalam Pasal 55 Undang - undang No 24 Tahun 2011 tentang BPJS menyebutkan bahwa Pemberi Kerja yang melanggar ketentuan sebagaimana dimaksud dalam Pasal 19 ayat (1) atau ayat (2) dipidana dengan pidana penjara paling lama 8 (delapan) tahun atau pidana denda paling banyak Rp1.000.000.000,00 (satu miliar rupiah). Dalam pasal tersebut juga tidak disebutkan nilai iuran yang tertunggak yang dapat dipidanakan, namun penetapan pidana penjara dan denda pidananya dengan nilai maksimal sudah disebutkan.

Dengan diterbitkannya Undang-Undang tersebut, seharusnya perusahaan sudah menyadari akan kewajibannya dan berupaya untuk tidak dinyatakan melakukan pelanggaran hukum. Pada kenyataannya perusahaan masih saja banyak yang melanggar. Pekerja akan menjadi korban dari kesalahan dari perusahaan dan akan mengakibatkan kerugian materiil yang cukup besar. Pada kenyataannya sanksi seperti yang disebutkan dalam Undang-undang tersebut sering tidak dilaksanakan sesuai dengan ketentuan yang berlaku. Terutama dalam hal pengenaan sanksi administratif, salah satunya adalah berupa pencabutan ijin usaha. Pencabutan ijin usaha akan berakibat perusahaan tutup dan akan semakin mempersulit para pekerjanya. Pengurusan ijin perusahaan yang ringan yang biasanya dibutuhkan juga oleh perusahaan adalah pengurusan ijin domisili, lingkungan maupun ijin mendirikan bangunan bilamana perusahaan sedang membangun fasilitas gedungnya. Bilamana perusahaan tidak membayar iuran, seharusnya BPJS Ketenagakerjaan secara cepat berkoordinasi dengan instansi kelurahan dan kecamatan untuk pengurusan ijin-ijin perusahaan tersebut.

Salah satu mitra penegak hukum bagi BPJS adalah Dinas Tenaga Kerja. Bila diketahui sebuah perusahaan melakukan pelanggaran, bisanya Dinas Tenaga Kerja hanya memberikan surat peringatan. Dinas Tenaga Kerja juga memperhitungkan kemungkinan resiko terburuk bilamana perusahaan tutup dan tidak bisa menjalankan 
roda operasional perusahaan dengan lancar. Berapa banyak pekerja yang akan menganggur dan akan menjadi permasalahan sosial yang baru. Perusahaan dapat mengajukan permohonan keringanan dalam menjalankan usahanya dan berupaya menunjukkan itikad baik dengan alasan untuk mempertahankan eksistensi usaha dan sekaligus mempertahankan para pekerjanya agar tetap dapat bekerja dengan baik dan tidak perlu adanya PHK. Surat peringatan bagi perusahaan yagn tidak membayar iuran BPJS Ketenagakerjaan juga dapat dikeluarkan oleh Kejari dalam hal ini terkait dengan adanya SKK dari BPJS Ketenagakerjaan.

Bila dilihat dari sisi pekerja sebagai korban dari tidak terlaksananya kewajiban perusahaan, maka mereka juga berhak untuk mendapatkan perlindungan hukum yang lebih pasti agar hak-hak mereka dapat terpenuhi berkaitan dengan manfaat dari program BPJS Ketenagakerjaan.

\section{Perlindungan Hukum Bagi Pekerja}

Sebelum lahirnya undang-undang tentang BPJS untuk pertama kali masalah perlindungan tenaga kerja ini telah diatur dalam bab IV, Pasal 9 Undang-Undang Nomor 14 Tahun 1969 tentang pokok-pokok tenaga kerja. Dan sebagai tindak lanjut juga diatur dalam pasal 27 Undang-Undang Nomor 3 tahun 1992 tentang Jaminan Sosial Tenaga Kerja yang menyebutkan bahwa pengendalian terhadap penyelenggaraan program jaminan sosial tenaga kerja oleh badan penyelenggara, sebagaimana dimaksud dalam undang-undang Nomor 24 tahun 2011 dilakukan oleh Badan Penyelenggara Jaminan Sosial di bawah Presiden. Pemerintah terlibat dalam pengawasannya, dan mengikutsertakan unsur Pemerintah yang membawahi ketenagakerjaan, pengusaha dan unsur pekerja, dalam wadah yang menjalankan fungsi Undang-undang yang berlaku. Pengawasan ketenagakerjaan diarahkan kepada usaha preventif dan edukatif. Namun demikian tindakan represif baik yang yustisial maupun non-yustisial dapat dilaksanakan secara bertahap. ${ }^{18}$

\footnotetext{
18 Jemikan, 'Kajian Yuridis Terhadap Pelaksanaan Bpjs Ketenagakerjaan Di Lingkungan Yayasan Perguruan 17 Agustus 1945 Surabaya' (2018) 14 DIH.[6].
} 
Pengawasan terhadap perusahaan oleh pemerintah dalam program Jaminan Sosial merupakan hal yang penting untuk memastikan perlindungan hukum terhadap tenaga kerja dibawah naungan Perusahaan. Tujuan dari pengawasan itu adalah agar dapat memantau pelaksanaan Undang-undang Nomor 24 Tahun 2011 tentang BPJS, sehingga undang-undang tersebut berjalan lebih efektif..

Sanksi yang diberikan kepada Perusahaan merupakan upaya penegakan hukum oleh Pemerintah terkait dengan upaya memberikan perlindungan hukum kepada masyarakat terutama pekerja di lingkungan Perusahaan yang tidak membayar iuran BPJS Ketenagakerjaan.

Penegakan hukum ini termasuk dalam ranah hukum pidana berkaitan langsung dengan sanksi pidananya, sedangkan penegakan hukum dalam ranah hukum perdata berkaitan erat dengan ganti kerugian. Sanksi pidana yang berkaitan dengan perusahaan biasanya meliputi hukuman penjara, hukuman denda dan hukuman kurungan Sedangkan sanksi perdata yang berkaitan dengan perusahaan adalah ganti rugi atas kerugian atau kerusakan yang telah ditimbulkan.$^{19}$

Selain sanksi-sanksi tersebut, penegakan hukum yang dilakukan oleh pemerintah dalam rangka perlindungan jaminan sosial tenaga kerja berhubungan dengan pemberian sanksi administratif yaitu tidak mendapatkan layanan publik. Sedangkan mengenai sanksi administrasi diatur tersendiri melalui Peraturan Pemerintah Nomor 86 Tahun 2013 tentang Tata Cara Pengenaan Sanksi Administrasi Kepada Pemberi Kerja selain Penyelenggara Negara, Hukum harus dilaksanakan dan ditegakkan. Hukum itu harus berlaku, dan dilaksanakan dengan cara tidak boleh menyimpang. Dengan cara demikian, maka ada kepastian hukum dan kepastian hukum akan menciptakan tertib masyarakat, karena menurut Sudikno Mertokusumo dan A. Pitlo "tujuan hukum adalah menciptakan kepastian hukum demi ketertiban masyarakat", ${ }^{20}$

\footnotetext{
${ }^{19}$ Sukarton Marmosujono, Penegakan Hukum Di Negara Pancasila (Pustaka Kartini 1980). $[20]$.

${ }^{20}$ Sudikno dan A Pitl Mertokusumo, Bab-Bab Tentang Penemuan Hukum, Citra Aditya Bakti, Kerjasama Konsorsium Ilmu Hukum (Citra Aditya Bakti 1993).[hal 68].
} 
Hans Kelsen mengemukakan pendapatnya tentang keadilan dalam bukunya General Theory of Law and State. Hans Kelsen berpandangan bahwa "Hukum sebagai tatanan sosial yang dapat dinyatakan adil apabila dapat mengatur perbuatan manusia dengan cara yang memuaskan sehingga dapat menemukan kebahagian didalamnya". ${ }^{21}$ Pandangan Hans Kelsen ini menyatakan bahwa nilai-nilai keadilan individu dapat diketahui dengan aturan-aturan hukum yang mengakomodir nilai-nilai umum, namun pemenuhan rasa keadilan dan kebahagian diperuntukan tiap individu.

Terkait dengan perusahaan yang melakukan pelanggaran peraturan perundang-undangan, Kejaksaan memiliki kewenangan untuk mengajukan permohonan Pembubaran Perseroan Terbatas sebagaimana yang dinyatakan dalam Peraturan Jaksa Agung No: PER-025/A/JA/11/2015 tentang Petunjuk Pelaksanaan Penegakan Hukum, Bantuan Hukum, Pertimbangan Hukum, Tindakan Hukum Lain dan Pelayanan Hukum di Bidang Perdata dan Tata Usaha Negara. Tidak menutup kemungkinan bagi Kejaksaan untuk mengajukan permohonan pembubaran suatu perseroan terbatas yang melakukan pelanggaran terhadap UU No. 24 Tahun 2011, baik perusahaan yang melanggar pasal 15, Pasal 16 dan Pasal 17 yang dikenakan sanksi administratif antara lain berupa : sanksi tidak dikeluarkannya IMB, tidak dikeluarkannya izin usaha sampai dengan perpanjangan SIM (PP No. 86 Tahun 2003), maupun yang melanggar Pasal 19 UU No. 24 tahun 2011.22

Dalam melaksanakan kewenangannya selaku Pengacara Negara, Kejaksaan mendukung kinerja dari BPJS Ketenagakerjaan melalui SKK (Surat Kuasa Khusus) untuk "bergerak". Baik dalam memberikan bantuan hukum litigasi dan non litigasi berupa negosiasi, mediasi, bahkan memfasilitasi pertemuan antara perusahaanperusahaan dengan pihak BPJS Ketenagakerjaan, maupun penegakan hukum dalam hal ini mewakili BPJS Ketenagakerjaan selaku pihak pengugat maupun tergugat di dalam Pengadilan, sehingga Kejaksaan dalam melaksanakan kewenangannya dibatasi sesuai dengan Surat Kuasa dari pihak BPJS Ketenagakerjaan. Peran

${ }^{21}$ Hans Kelsen, Pengantar Teori Hukum (Nusamedia 2011).[7].

${ }^{22}$ Sulvia Triana Hapsari, 'Permasalahan Penegakan Hukum Dalam Upaya Penyelesaian Masalah BPJS Ketenagakerjaan' (Kejari Jakarta Barat, 2016) <www.kejari-jakbar.go.id>. 
Kejaksaan sebenarnya adalah sebagai penengah antara Perusahaan dengan BPJS Ketenagakerjaan untuk menangani kasus penunggakan iuran ini. Namun Kejari tidak dapat bertindak sebelum BPJS Ketenagakerjaan mengeluarkan SKK tersebut. ${ }^{23}$

Penegak hukum terakhir yang memiliki kewenangan dalam melakukan penyidikan tindak pidana ketenagakerjaan maupun yang dimaksud dalam pasal 1 KUHAP yaitu: Pejabat Polisi Negara RI atau PPNS tertentu yang diberi wewenang khusus oleh UU untuk melakukan penyidikan. Bagi kepolisian yang melaksanakan penegakan hukum terkait tindak pidana sebagaimana yang terdapat dalam pasal 55 UU No. 24 Tahun 2011 tentunya berpedoman kepada pasal 7 ayat (2) Kitab UndangUndang Hukum UU No. 8 Tahun 1981 tentang Hukum Acara Pidana dimana pihak kepolisian tetap memiliki kewajiban untuk mengawasi PPNS lainnya. ${ }^{24}$

Hal yang perlu dicermati adalah BPJS Ketenagakerjaan tidak memberikan landasan dalam menentukan perusahaan yang berhak ditindak pidana dan mana perusahaan yang masih bisa dianggap kooperatif. Demikian juga dengan perusahaan yang menunggak selama ber-bulan bulan atau menunggak dengan nilai yang tinggi hingga Milyaran - dibanding dengan perusahaan yang hanya menunggak beberapa bulan dengan nilai yang masih dibawah 1 Milyar.

BPJS Ketenagakerjaan seharusnya kooperatif dan berupaya untuk terus mengejar atau menghimbau perusahaan agar membayarkan iurannya. Good Will dari perusahaan harus ditunjukkan juga kepada BPJS Ketenagakerjaan agar mereka dapat ditolerir, sebaliknya BPJS Ketenagakerjaan juga harus menunjukkan sikap terbuka untuk membantu perusahaan yang menunjukkan itikad baik untuk melunasi tunggakannya. Berbeda dengan perusahaan yang dengan sengaja menghindari untuk membayar iuran tersebut.

\section{Kesimpulan}

Berdasarkan pembahasan dalam penulisan ini, maka dapat disimpulkan bahwa Pemerintah memberikan perlindungan hukum kepada para pekerja di perusahaan
23 ibid.
24 ibid. 
yang tidak membayar iuran BPJS Ketenagakerjaan dengan mengeluarkan Peraturan Menteri Tenaga Kerja No. 23 tahun 2016 tentang Prosedur Pengenaan dan Pencabutan Sanksi Administratif Tidak Mendapatkan Layanan Publik Tertentu untuk Pengusaha Selain Administrator Negara dan Undang-Undnag No 24 Tahun 2011 tentang BPJS pada Pasal 17 dan Pasal 55. Khusus sanksi pidana pada pasal 55 ini BPJS Ketenagakerjaan memiliki kebijakan dan kewenangan khusus untuk mengajukan tuntutan sanksi pidana ini.

Penerapan sanksi kepada perusahaan tidak berdasarkan pada nilai iuran yang tertunggak, melainkan berdasarkan pada periode waktu dimana iuran tersebut tidak dibayarkan. Hal ini mengakibatkan perusahaan yang menunggak 1 juta ataupun 100 juta bisa saja mendapatkan teguran yang sama dari Kejari sesuai dengan SKK yang diberikan oleh BPJS Ketenagakerjaan. Sanksi Administrasi dan denda mulai diberlakukan bila perusahaan tidak membayar iuran selama 3 bulan berturut-turut. Sanksi akan dicabut bilamana perusahaan melunasi tunggakannya. Selama tunggakan tidak dilunasi maka pekerja tidak dapat menerima benefit dari BPJS Ketenagakerjaan. Pada pasal 55 dalam UU No 24 tahun 2011 tentang BPJS tidak menyebutkan mengenai nominal tunggakan melainkan hanya menyebutkan bahwa bila perusahaan tidak membayar iuran maka dapat dikenakan denda dan sanksi pidana. Hal ini dapat membuat celah subyektivitas pada Hakim dalam mengambil Keputusan dan semakin membuka peluang ketidakpastian bagi pekerja untuk mendapatkan perlindungan hukum atas hak-hak mereka.

Demi memberikan perlindungan hukum atas hak para pekerja, BPJS Ketenagakerjaan membuka kesempatan untuk melakukan musyawarah dengan perusahaan berkaitan dengan tunggakan yang belum dibayarkan oleh perusahaan. Bila tidak tercapai mufakat antara perusahaan dan BPJS Ketenagakerjaan sehingga terjadi kondisi dimana para pekerja tidak mendapatkan benefit dari program yang telah diikutinya selama bertahun-tahun karena tidak dapat klaim kepada BPJS Ketenagakerjaan, maka para pekerja dapat menuntut perusahaan secara hukum yang berlaku melalui Pengadilan Negeri. 
Penegak hukum yang memiliki kewenangan untuk mengawasi dan memberikan sanksi kepada perusahaan yang tidak membayar iuran BPJS Ketenagakerjaan adalah: Kejaksaan, Sudinakertran dan Polisi. Mitra BPJS Ketenagakerjaan ini dituntut untuk dapat bertindak dengan tegas dalam melaksanakan kewenangannya sehingga diharapkan perusahaan tidak lalai menjalankan kewajibannya dan para pekerja mendapatkan haknya berkaitan dengan benefit dari BPJS Ketenagakerjaan.

\section{Daftar Pustaka}

\section{Buku}

Hans Kelsen, Pengantar Teori Hukum (Nusamedia 2011).

Hardijan Rusli, Metode Penelitian Hukum Normatif: Bagaimana? (Law Review 2006).

Marmosujono S, Penegakan Hukum Di Negara Pancasila (Pustaka Kartini 1980).

Mertokusumo S dan AP, Bab-Bab Tentang Penemuan Hukum, Kerjasama Konsorsium Ilmu Hukum (Citra Aditya Bakti 1993).

—_, Penemuan Hukum Sebuah Pengantar (2009).

Peter Mahmud Marzuki, Penelitian Hukum 2009 (Kencana Prenada Media Group 2009).

Soerjono Soekanto dan Sri Mamudji, Penelitian Hukum Normatif Suatu Tinjauan Singkat (Raja Grafindo Persada 2009).

\section{Jurnal}

Jemikan, 'Kajian Yuridis Terhadap Pelaksanaan Bpjs Ketenagakerjaan Di Lingkungan Yayasan Perguruan 17 Agustus 1945 Surabaya' (2018) 14 DIH.

\section{Perundang-undangan}

Undang-Undang Nomor 14 Tahun 1969 tentang Pokok-Pokok Tenaga Kerja.

Undang-undang Nomor 3 tahun 1992 tentang Jaminan Sosial Tenaga Kerja

Undang-Undang No. 24 tahun 2011 tentang BPJS. 
Undang-Undang No. 40 tahun 2004 tentang Jaminan Sosial Nasional.

Undang-undang No. 40 tahun 2007 tentang Perseroan Terbatas.

Kitab Undang-Undang Hukum Undang-Undang No. 8 Tahun 1981 tentang Hukum Acara Pidana.

Peraturan Pemerintah Nomor 86 Tahun 2013 tentang Tata Cara Pengenaan Sanksi Administratif kepada Pemberi Kerja Selain Penyelenggara Negara dan Setiap Orang, Selain Pemberi Kerja, Pekerja, dan Penerima Bantuan Iuran dalam Penyelenggara Jaminan Sosial.

Peraturan Pemerintah Nomor 44 Tahun 2015 tentang Penyelenggaraan Program Jaminan Kecelakaan Kerja dan Jaminan Kematian.

Peraturan Pemerintah Nomor 45 Tahun 2015 tentang Penyelenggaraan Program Jaminan Pensiun.

Peraturan Menteri Tenaga Kerja No. 23 tahun 2016 tentang Prosedur Pengenaan dan Pencabutan Sanksi Administratif Tidak Mendapatkan Layanan Publik Tertentu untuk Pengusaha Selain Administrator Negara.

Peraturan Menteri Tenaga Kerja No 19 Tahun 2015 tentang Tata Cara Pembayaran Manfaat JHT.

Peraturan Menteri Ketenagakerjaan Nomor 26 Tahun 2015 tentang Tata Cara Penyelenggaraan Program Jaminan Kecelakaan Kerja, Jaminan Kematian, dan Jaminan Hari Tua Bagi Peserta Penerima Upah

Peraturan Menteri Ketenagakerjaan Nomor 29 Tahun 2015 tentang Tata Cara Pendaftaran Kepesertaan, Pembayaran dan Penghentian Manfaat Jaminan Pensiun.

Peraturan Jaksa Agung No: PER-025/A/JA/11/2015 tentang Petunjuk Pelaksanaan Penegakan Hukum, Bantuan Hukum, Pertimbangan Hukum, Tindakan Hukum Lain dan Pelayanan Hukum di Bidang Perdata dan Tata Usaha Negara.

\section{Laman}

Sulvia Triana Hapsari, 'Permasalahan Penegakan Hukum Dalam Upaya Penyelesaian Masalah BPJS Ketenagakerjaan' (Kejari Jakarta Barat, 2016) <www.kejarijakbar.go.id $>$.

HOW TO CITE: Nurfatimah Mani, 'Perlindungan Hukum bagi Pekerja di Perusahaan yang Tidak Membayar Iuran BPJS Ketenagakerjaan' (2019) Vol. 2 No. 3 Media Iuris. 